\title{
Health and Reproductive Outcomes among American Legionnaires in Relation to Combat and Herbicide Exposure in Vietnam ${ }^{1}$
}

\author{
Steven D. Stellman, ${ }^{*, 2}$ Jeanne Mager Stellman,$\dagger$ and \\ JOHN F. SOMMER, JR. $¥$ \\ ${ }^{*}$ Department of Epidemiology and Statistics, American Cancer Society, New York, New York; \\ $\dagger$ School of Public Health, Columbia University; and $¥$ National Veterans Affairs and Rehabilitation \\ Commission, The American Legion, Washington D.C.
}

Received November 2, 1987

\begin{abstract}
History of diagnosed illnesses, medical symptoms, and reproductive outcomes and their relation to combat intensity and herbicide exposure were studied, via a mailed questionnaire, among 6810 American Legionnaires who served during the Vietnam War (42\% in Southeast Asia, 58\% elsewhere). Heart disease, venereal disease, and benign fatty tumors were reported significantly more often by Vietnam veterans than by controls. Combat intensity was significantly dosage-related to history of high blood pressure, ulcers, arthritis and rheumatism, genito-urinary problems, nervous system disease, major injury, hepatitis, and benign fatty tumors. Agent Orange exposure was significantly dosage-related to history of benign fatty tumors, adult acne, skin rash with blisters, and increased sensitivity of eyes to light. Rates of the latter two conditions and of change in skin color were especially elevated in men whose military occupations involved direct handling of herbicides. Five "symptom complex" scales were constructed via factor analysis to measure degrees of feeling faint, fatigue or physical depression, body aches, colds, and skin irritation. Means of all five scales were significantly higher in Vietnam veterans compared to controls, and in herbicide handlers compared to nonhandlers. Both combat and Agent Orange exposure were significant, independent predictors of each of the five scales. Neither combat nor Agent Orange exposure was associated with difficulty in conception, time to conception of first child, or to birthweight or sex ratio of offspring, but maternal smoking was strongly related to reduced birthweight. The percentage of spouses' pregnancies which resulted in miscarriages was significantly higher for Vietnam veterans than controls $(7.6 \%$ vs $5.5 \%$, $P<0.001)$. Logistic regression analysis showed that Agent Orange exposure and maternal smoking were both independently and significantly associated with miscarriage rates in a dose-related manner. 1988 Academic Press, Inc.
\end{abstract}

\section{INTRODUCTION}

This is the third paper in a series of reports concerning the health and well-being of Vietnam veterans who belong to The American Legion. In it we consider physical and reproductive health among the Legionnaire study population. In the first paper of the series we gave details of the methodology, presented demographic characteristics of the study population, and described the distributions of

\footnotetext{
${ }^{1}$ Address reprint requests to Foundation for Worker, Veteran and Environmental Health, Inc., 117 St. Johns Place, Brooklyn, NY 11217.

2 Present address: New York City Department of Health, New York, NY 10013.
} 
combat and herbicide exposure among study subjects (Stellman et al., 1988a). In a second paper, we described the relationship between the Vietnam experience and a variety of social and behavioral outcomes, including family and parental attitudes, divorce, income, drinking, and smoking (Stellman et al., 1988b). In the latter paper, combat had a powerful, quantitative impact on nearly every aspect of the veterans' lives considered, while herbicide exposure was related only to a few outcomes, and then as an "interactive" term with combat, and not as an independent predictor.

The possible human health effects associated with herbicides are a matter of great public and professional debate and concern. The ingredients of Agent Orange, the major herbicide used in Vietnam, have been known to be toxic in experimental systems for many years. 2,4,5-T is embryotoxic and teratogenic to the mouse (Courtney and Moore, 1971; Neubert and Dillmann, 1972; Hood et al., 1979), causes fetal anomalies in hamsters (Collins and Williams, 1971), and induces a variety of genotoxic effects in numerous animal and plant species (Grant, 1979). Information on the experimental toxicity of $2,4-\mathrm{D}$, the other major component of Agent Orange, has also been available for many years. 2,4-D in large doses has been found to poison both experimental animals and livestock (Rowe and Hymas, 1954; Fenton, 1984). When given orally to rats, 2,4-D was found to be embryotoxic and fetotoxic but not teratogenic (Schwetz et al., 1971).

Of major toxicological importance to Vietnam veterans and to some people with occupational and community exposures is the contamination of 2,4,5-T with 2,3,7,8-tetrachloro- $p$-dibenzodioxin (TCDD) and its congeners. In laboratory animals, TCDD has been found to be extremely toxic in many studies (Neal, 1984). The $\mathrm{LD}_{50}$ in guinea pigs is less than $2 \mu \mathrm{g} / \mathrm{kg}$ of body weight (Huff et al., 1980; Schwetz et al., 1973). At subacute doses, it produces many other systemic effects. TCDD is also embryotoxic and teratogenic to several strains of rats and mice (Courtney and Moore, 1971) and is carcinogenic by several routes of administration (International Agency for Research on Cancer, 1977; Van Miller et al., 1977; Kociba et al., 1978).

The 2,4,5-T used in Agent Orange was heavily contaminated with dioxins (Young et al., 1978). According to Young and co-workers the mean concentration in Agent Orange was $2 \mathrm{ppm}$. Individual lot concentrations ranged from 0.05 to about $30 \mathrm{ppm}$.

Despite the large number of experimental studies which have consistently demonstrated the toxicity of dioxins and of 2,4,5-T in animals, the effects of TCDD and herbicide exposures on humans are still not well delineated or understood. Until recently, information on health effects of these compounds came largely from clinical and epidemiological studies of occupationally exposed workers. In recent years a number of environmental incidents such as those at Seveso, Italy, and Times Beach, Missouri, have led to studies of exposure consequences in the general population (Patterson et al., 1986).

In clinical evaluations of exposed workers and others, a wide range of dermatological, metabolic, neurological, and behavioral effects have been observed (Huff et al., 1980). Some, like chloracne, date from the early part of the century (Herxheimer, 1901). A recent study of 154 Missouri residents who were believed 
to have been exposed to dioxin-contaminated waste oil, revealed some liver function changes and statistically significant differences in immune system response. The incidence of clinical disease was not, however, greater than expected (Hoffman et al., 1986). Other studies have suggested that nonspecific conditions or symptoms, such as fatigue, dizziness, and nausea might also be related to herbicide exposure (Poland et al., 1971; Bogen, 1979; Stellman and Stellman, 1980).

Much epidemiological work has focused on cancer. Many investigators have linked occupational exposure to phenoxy herbicides to an increased risk for softtissue sarcoma (Hardell and Sandstrom, 1979; Eriksson et al., 1981; Lynge, 1985; Vineis et al., 1986) and for non-Hodgkins lymphoma (Hardell et al., 1981; Hoar et al., 1986; Woods et al., 1987; Pearce et al., 1985). In several other studies, however, these relationships have not been confirmed (Wiklund and Holm, 1986; Pearce et al., 1986).

The largest identifiable group with potential exposure to herbicides is undoubtedly Vietnam veterans. Concern for possible health consequences of such exposures has led to initiation of a number of studies; few have been completed, however, and many are of lengthy duration. In 1979, the U.S. Air Force launched a long-term morbidity and mortality study of 2706 men who participated in Operation Ranchhand, the aerial herbicide dissemination project in Vietnam (Lathrop et al., 1984). The study includes periodic clinical evaluation of subjects and a control group; some study segments are projected to extend at least 20 years. The protocol for largest study of Vietnam veterans, mandated by Congress in 1979 and to be carried out by the Centers for Disease Control, has still not been finalized and the study has many controversial aspects.

Mortality has been a common endpoint of Vietnam veteran studies (Lawrence et al., 1985; Kogan and Clapp, 1985; Bailey et al., 1986; Fett et al., 1987a, b; Centers for Disease Control, 1987; Breslin et al., 1988).

Mortality studies suffer two major shortcomings with respect to assessing postservice health effects. First, the Vietnam War cohort is still quite young, and death rates are correspondingly low. Cancer deaths are rare, having generally longer latencies than the time so far elapsed since the war's end.

Secondly, no published mortality study has quantitatively considered either combat level or herbicide exposure. As we demonstrated earlier in this series, it is not legitimate to consider service in Southeast Asia a proxy for either exposure. Therefore, no completed mortality study is informative on the influence of these factors, while the small number of subjects included in the ongoing Ranchhand study inherently limits its potential to provide detailed comparative mortality data, especially for specific causes of death.

A further area of concern is the reproductive health of Vietnam veterans. At baseline, the Ranchhand study showed no significant differences compared to control groups in conception outcomes such as prematurity, miscarriages, stillbirths or "severe" birth defects. However, the study did show an excess of "minor" defects, as well as a significant excess of neonatal deaths and physical handicaps (Lathrop et al., 1984).

The CDC completed a case-control study of babies born in the metropolitan Atlanta area and concluded that Vietnam veterans in general did not have an 
increased risk of fathering babies with defects (all types combined) (Erickson $e t$ al., 1984a, b). Nevertheless, veterans judged by the CDC to be "exposed" to Agent Orange had significantly higher risks of having children with birth defects including spina bifida, cleft lip with or without cleft palate, and a miscellaneous constellation of neoplasms. Donovan et al. (1984) have reported that the risk for Australian Vietnam veterans to have fathered a child with a birth defect was no different than that of other Australian men.

Given this background of the potential adverse health effects of exposure to the highly toxic herbicidal agents used in Vietnam, one aim of the present study was to investigate the self-reported health status of a cohort of Vietnam veterans with varying degrees of exposure to herbicides and in comparison to Vietnam Era veteran peers with no service in Southeast Asia. Because herbicide exposure and exposure to intense combat are correlated, the study also sought to clarify the general health effects of exposure to the stressful conditions of intense combat.

It is important to note that the American Legion study was not designed to investigate the possible relationship between herbicide exposure and the development of malignancies. Because of the low background rates of all types of cancer in a group with this age distribution, the present study does not have the statistical power to detect such effects. Also, for the majority of the cohort, insufficient time has elapsed for the natural latency of the disease process to have passed.

\section{METHODS}

The study has a cross-sectional design in which various outcome measures are compared between groups of men who served in the U.S. Armed Forces in Southeast Asia during the Vietnam War (1961-1975), and men who served elsewhere during the same period. The men were randomly selected from the membership rosters as of October 15, 1983, in six Departments of the American Legion, encompassing the states of Colorado, Indiana, Maryland, Minnesota, Ohio, and Pennsylvania. The random sampling procedures and details of the selection process are given in an earlier paper in this series (Stellman et al., 1988a).

The survey consisted of a self-administered questionnaire requiring between 45 min and $1 \mathrm{hr}$ for completion. Several sections of the questionnaire were designed to measure the health outcomes of interest here, as well as social, behavioral, and pyschological outcomes treated in the other papers of this series.

General health conditions. One section was designed to answer three questions about general health outcomes: is the history of a specific health condition (such as hepatitis) given more frequently by men who served in SEA (in-country) than in men who served elsewhere (controls)? Among men with Southeast Asia service, is history of a health condition more frequent among those whose jobs involved handling herbicides than among those with other jobs? Among those men whose jobs did not require them to handle herbicides, is the history of a health condition quantitatively related either to exposure to herbicides or to level of combat?

Subjects were asked whether they had ever been informed by a doctor that they had certain specific diseases or conditions. They could check "yes" or "no" to any of 23 different diseases, and were asked to furnish the date the diagnosis was 
first made. Only conditions diagnosed no earlier than 1 year prior to discharge are counted, in order to eliminate health conditions which preexisted military service.

In addition to medically diagnosed conditions, subjects were asked whether they had experienced a number of other conditions suggested in the literature to be related to exposure to phenoxy herbicides, such as acne, skin rash with blisters, or changes in skin color, or whether any part of their body had become more sensitive to light. These conditions are called "questionnaire derived" to distinguish them from medically diagnosed conditions.

Health symptoms. It has been widely suggested that exposure to herbicides or other dioxin-containing substances does not always cause specific illnesses, but can cause or exacerbate physical symptoms or complexes of symptoms (Poland et al., 1971; Bogen, 1979; Stellman and Stellman, 1980; Suskind and Hertzberg, 1984). In their review of studies of workers exposed to phenoxy herbicides, Young and colleagues enumerated a variety of reported "signs, symptoms, and disorders," which included headaches, neuralgia or myalgia, paresis, hemorrhage, porphyria, hyperpigmentation or hirsutism, acne, asthenia, abdominal pain or pressure, anorexia, nausea, vomiting, diarrhea, and psychiatric disorders (Young et al., 1978, p VI-14). Identification of herbicide exposure as a cause of some of these symptoms or conditions can be more difficult than for specifically diagnosable diseases, because of the inherent ambiguity of outcome definition, and the relatively higher degree of subjectivity both in answering questions and in interpreting the responses.

Subjects were asked to rate the extent to which each of 28 specific health conditions was "currently a problem" by circling a number: 1 (not a problem), 2 (a minor problem), 3 (a problem), or 4 (really a major problem). For each item, the subject was asked whether the problem predated military service, whether medical attention was sought, and if so when. Analyses were restricted to those conditions which first appeared 1 year or more following discharge. Factor analysis of the entire set of 28 items, using principal component analysis followed by varimax rotation (SPSS-X) was carried out and produced five well-separated factors, each of whose components appeared to represent a distinct health outcome dimension.

Five symptom scales were constructed from those sets of items which factor analysis had shown to be most clearly related to each other, and their reliabilities ascertained. These scales measure symptoms related to faintness (the scale is thus named Faint), fatigue or physical depression (Fatigue), aches and pains (Aches), colds (Colds), and skin effects (Skin). In this manner the information contained in the original 28 variables could be economically represented by five distinct, coherent, and meaningful scale variables.

Reproductive health. We obtained data on the family history of the study population, including data on reported difficulties with conception, specific birth outcomes, maternal smoking habits and age, birthweight, and the seeking of medical assistance for perceived problems with reproductive health and functioning. Because of the necessity of obtaining medical verification of reported birth defects, which has not yet been completed, the data presented here are restricted to analysis of childbearing attempts, reported difficulties in having children, delays in fathering, family size, incidence of miscarriages, and sex ratio of offspring but 
not birth defects. The reproductive findings are confined to men born in 1940 or later, in order to eliminate reproductive experiences which occurred before the Vietnam War.

Combat and herbicide exposure. Exposure to the two etiologic factors of interest, combat and herbicides, was quantified by methods that were described in detail in the first paper of this series (Stellman et al., 1988a). In brief, combat was measured by an eight-item scale (range 8-40) using a set of questions which queried the extent of enemy fire and life-threatening situational exposures. These questions were designed to be compatible with other studies on combat-related effects (Frye and Stockton, 1982; Figley, 1978; Roberts et al., 1982). Herbicide exposure is expressed as the Agent Orange score, OE3. This previously published evaluation method (Stellman and Stellman, 1986) assigns to each subject a numerical probability score, based upon a comparison of his questionnaire-derived service locations in Vietnam with the combined Air Force and U.S. Army Joint Services Environmental Support Group records or spraying locations (HERBS tapes and Services HERBS tapes). It gives higher weighting to closer distances to spraying, and to more recent exposures, and allows for exponential decay of an "active ingredient."

Statistical analysis. Distributions of histories of medical conditions were compared between population subgroups using the Mantel-Haenszel $\chi^{2}$ test with one degree of freedom (Mantel and Haenszel, 1959). Mantel-Haenszel odds ratios (OR) were computed to determine the relative odds (1) for each health condition as a function of combat and (2) for each condition as a function of herbicide exposure (Mantel and Haenszel, 1959). Subjects were stratified by combat (three levels) or by herbicide score (three levels), and dose-responses were tested using the Mantel extension test (Mantel, 1963). Such analyses were restricted to men who served in Vietnam, but who did not hold specific herbicide-related jobs. The latter group were analyzed separately.

Mean values of continuous variables, such as the symptom scales, were compared between subgroups via $t$ tests. The joint effects of combat and herbicide exposure were assessed via multiple regression, logistic regression, and analysis of covariance. In these analyses, both exposure variables were used in their original continuous forms.

Owing to lack of association between age and either the combat or herbicide exposure indices ( $r=0.01$ and -0.02 , respectively), as well as to the extremely narrow age distribution of subjects ( $87 \%$ of subjects were born between 1940 and 1950), age-adjustment was generally not done. Nevertheless, additional ageadjustment (in 2-year age strata) was done for those health outcomes which initially yielded statistically significant results. These included history of heart disease and elevated blood pressure, which are well known to be age-related.

\section{RESULTS}

\section{Subject Selection and Exposure Classification}

Of the 6810 men who returned completed questionnaires, $2858(42.0 \%)$ had served in Southeast Asia and 3933 had served elsewhere. Service location could 
not be determined for 19 men. As explained in Paper 1 (Stellman et al., 1988a), our study population reflects deliberate oversampling of Vietnam veterans in order to obtain sufficient numbers of subjects for statistically meaningful analyses of health and other endpoints.

Combat scores, which ranged from 8 to 40 , could be computed for all but 13 Southeast Asia veterans. Categories were assigned as follows: low combat (up to 15), 1209 men (42.5\%); medium combat (16-25), 1084 men (38.1\%); high combat 26-40), 552 men (19.4\%). Agent Orange exposure, which ranged from 0.0 to 9.9 , was available for 2087 men and was categorized as low exposure ( 0 to 0.097$), 947$ men (45.4\%); medium exposure (0.098 to 0.308$)$, 583 men (27.9\%); high exposure (above 0.308), 557 men (26.7\%). These categorizations were chosen, rather than, say, tertiles, to provide sufficient subjects in each of the nine combinations to allow adjustment for either variable after stratification by the other.

\section{Health Conditions}

Southeast Asia vs elsewhere. Table 1 shows the percentage of men checking "yes" to any of the 11 medical conditions mentioned by more than $0.5 \%$ of all subjects. (Conditions with too few responses to tabulate included epilepsy, ane-

TABLE 1

Percentage Frequency and Odds Ratio in Favor of Having Been Medically Diagnosed with Specific Health Conditions according to Location of Military Service

\begin{tabular}{lccc}
\hline & \multicolumn{2}{c}{ Served in Southeast Asia } \\
\cline { 2 - 3 } \multicolumn{1}{c}{ Disease or condition } & Yes & No & \\
& $(N=2858)$ & Odds ratio \\
\hline Medically diagnosed & Percentage with history & \\
High blood pressure & & & 1.12 \\
Heart disease & $20.7 \%$ & $18.9 \%$ & $1.43^{*}$ \\
$\quad$ Age-adjusted & 3.4 & 2.4 & $1.45^{*}$ \\
Stomach or duodenal ulcer & & & 1.17 \\
Venereal disease & 10.4 & 9.0 & $1.82^{* * *}$ \\
Benign fatty tumors & 5.3 & 3.0 & $1.36^{* * *}$ \\
Arthritis or rheumatism & 12.5 & 9.5 & 1.07 \\
Hepatitis & 11.9 & 11.2 & 1.30 \\
Chronic bronchitis & 1.8 & 1.4 & 1.19 \\
Genito-urinary problems & 3.0 & 2.5 & 1.16 \\
Nervous system disease & 3.2 & 2.8 & 1.41 \\
Major injury & 2.0 & 1.4 & 1.07 \\
Questionnaire derived & 11.2 & 10.5 & 1.19 \\
Adult acne & & & $2.05^{* * *}$ \\
Skin rash with blisters & 12.3 & 10.5 & $2.55^{* * *}$ \\
Change in skin color & 19.8 & 10.7 & $1.73^{* * *}$ \\
Increased sensitivity to light & 8.5 & 3.5 & 12.3 \\
\hline
\end{tabular}

${ }^{a} N$ 's indicate number of men eligible to answer specific questions. Actual number of respondents varied slightly due to missing information.

${ }^{*} P<0.05 ;{ }^{* * *} P<0.001$. 
mia, sickle cell anemia, ulcerative colitis, tuberculosis, lupus, Addison's disease, and cancer). The distributions of these diseases and conditions are presented according to location of service, but without regard to intensity of combat or index of exposure to herbicide. Three other conditions not tabulated are kidney disease, diabetes, and varicose veins. History of these conditions did not vary significantly between any study subgroups.

Among the 11 listed medically diagnosed conditions, three were mentioned significantly more often among men who served in Southeast Asia: heart disease, benign fatty tumors, and venereal disease. Twelve and a half percent of these men reported having developed a benign fatty tumor (such as a sebaceous cyst) after having left the military service, compared to $9.5 \%$ of the control group that did not serve in Southeast Asia (OR $=1.36, P<0.001)$. Venereal disease was also reported more often in the Southeast Asia group, with a frequency of $5.3 \%$, compared to $3.0 \%$ in controls $(\mathrm{OR}=1.82, P<0.001)$. A history of heart disease was mentioned by $3.4 \%$ of the Vietnam subjects, and by $2.4 \%$ of controls (ageadjusted $\mathrm{OR}=1.45, P<0.05$ ).

Southeast Asia veterans also experienced significantly $(P<0.001)$ higher rates of three of the four questionnaire-derived items: skin rash with blisters $(O R=$ $2.05)$, change in skin color $(\mathrm{OR}=2.55)$, increased sensitivity to light $(\mathrm{OR}=1.73)$ (Table 1).

Herbicide handlers vs nonhandlers. Herbicide handlers were men who reported having held at least one of the following jobs in Vietnam: sprayer on an airplane, helicopter, or boat; loader or handler of herbicide for a plane, helicopter, or boat; or handler of herbicide during storage or shipment for other uses. Table 2 gives the percentage mentioning the 11 medical problems and the four questionnairederived items along with odds ratios for handlers relative to nonhandlers who served in Vietnam. Because of possible confounding by exposure to combat, these ORs have been adjusted for combat by the Mantel-Haenszel procedure.

The herbicide handlers had significantly elevated odds ratios $(P<0.05)$ for history of high blood pressure $(O R=1.68)$, heart disease $(O R=2.37)$, and ulcers $(\mathrm{OR}=1.76)$; when adjusted for age, the OR for heart disease decreased to 1.76 , but was no longer statistically significant. Age-adjustment, however, actually increased the ORs for other conditions; that for sensitivity to light became statistically significant $(\mathrm{OR}=1.99, P<0.01)$. Of special importance is the significantly greater combat-adjusted frequency of skin rash with blisters $(O R=2.52, P<$ $0.001)$ and for change in skin color $(\mathrm{OR}=2.47, P<0.001$ in herbicide handlers, relative to nonhandlers also who served in Southeast Asia.

Herbicide exposure effects. The relative odds for the indicated medical conditions in relation to Agent Orange exposure, as measured by the OE3 index, are shown in Table 3. Agent Orange exposure was dosage-related to a diagnosis of benign fatty tumors (OR in high-exposure group $=1.43, P$ for trend $<0.05$ ). Herbicide exposure was also significantly related to adult acne, skin rash with blisters, and increased sensitivity to light.

Combat effects. Because several of the medically diagnosed conditions are thought to be related to stressful life events (Levi, 1981), odds ratios for the effects 
TABLE 2

Odds Ratios in Favor of Having Been Medically Diagnosed with Specific Health Conditions among Herbicide Handlers in Southeast Asia, Relative to Nonhandlers Who Also Served in Southeast Asia

\begin{tabular}{|c|c|c|c|}
\hline \multirow[b]{2}{*}{ Disease or Condition } & \multicolumn{2}{|c|}{$\begin{array}{l}\text { Herbicide } \\
\text { handler }^{a}\end{array}$} & \multirow{2}{*}{$\begin{array}{l}\text { Odds ratio } \\
\text { (adjusted for } \\
\text { combat) }\end{array}$} \\
\hline & $\begin{array}{c}\text { Yes } \\
N=102\end{array}$ & $\begin{array}{c}\text { No } \\
2756\end{array}$ & \\
\hline Medically diagnosed & \multicolumn{2}{|c|}{ Percentage with history } & \\
\hline High blood pressure & $32.3 \%$ & $20.3 \%$ & $1.68^{*}$ \\
\hline Heart disease & 8.0 & 3.2 & $2.37^{*}$ \\
\hline Age-adjusted & & & 1.76 \\
\hline Stomach or duodenal ulcer & 19.5 & 10.1 & $1.76^{*}$ \\
\hline Venereal disease & 5.8 & 5.3 & 1.17 \\
\hline Benign fatty tumors & 17.9 & 12.3 & 1.33 \\
\hline Arthritis or rheumatism & 19.5 & 11.6 & 1.52 \\
\hline Hepatitis & 2.4 & 1.8 & 0.95 \\
\hline Chronic bronchitis & 5.7 & 2.9 & 1.79 \\
\hline Genito-urinary problems & 3.5 & 3.2 & 0.92 \\
\hline Nervous system disease & 4.7 & 1.9 & 1.77 \\
\hline Major injury & 9.5 & 11.2 & 0.76 \\
\hline \multicolumn{4}{|l|}{ Questionnaire derived } \\
\hline Adult acne & 12.9 & 12.2 & 0.99 \\
\hline Skin rash with blisters & 42.6 & 18.9 & $2.52^{* * *}$ \\
\hline Change in skin color & 22.2 & 8.0 & $2.47 * * *$ \\
\hline Increased sensitivity to light & 31.0 & 19.1 & 1.46 \\
\hline Age-adjusted & & & $1.99 * *$ \\
\hline
\end{tabular}

${ }^{a} N$ 's indicate number of men eligible to answer specific questions. Actual number of respondents varied slightly due to missing information.

${ }^{*} P<0.05 ;{ }^{* *} P<0.01 ;{ }^{* *} P<0.001$.

of combat in Vietnam upon these conditions are presented in Table 4. Level of combat was significantly related to history of high blood pressure, which ranged from $17.7 \%$ in men who experienced low combat, to $21.2 \%$ for medium combat, to $24.4 \%$ in the high combat group $(P<0.01)$. Even stronger relationships were found between combat and stomach/duodenal ulcers $(\mathrm{OR}=2.26$ for high vs low combat $)$, benign fatty tumors $(\mathrm{OR}=1.91)$, arthritis or rheumatism $(\mathrm{OR}=2.26)$, genito-urinary problems $(\mathrm{OR}=2.32)$, and major injury $(\mathrm{OR}=1.41)$. The highcombat group was four times as likely to have had hepatitis ( $O R=4.06, P<$ $0.001)$ and self-described "nervous system disease" ( $O R=4.32, P<0.001)$ compared to the low-combat group. All of these conditions exhibited doseresponses; that is, ORs increased with increasing level of combat.

The associations of combat and Agent Orange exposure with benign fatty tumors, thus far established in univariate analyses (Tables 3 and 4), were studied simultaneously via a logistic regression model. Both exposures were independent, statistically significant predictors of this condition. 
TABLE 3

Percentage Frequency and Odds Ratio in Favor of Having Been Medically Diagnosed with Specific Health Conditions among Veterans Who Served in Southeast Asia, but Who Held No Herbicide-Related Jobs, According to Level of Exposure to Agent ORANGE

\begin{tabular}{|c|c|c|c|c|c|c|}
\hline \multirow[b]{2}{*}{ Disease or condition } & \multicolumn{6}{|c|}{ Agent Orange exposure } \\
\hline & $\begin{array}{c}\text { Low } \\
N=947\end{array}$ & $\begin{array}{c}\text { Medium } \\
583\end{array}$ & $\begin{array}{c}\mathrm{High}^{a} \\
557\end{array}$ & Low & Medium & High \\
\hline Medically diagnosed & \multicolumn{3}{|c|}{ Percentage with history } & \multicolumn{3}{|c|}{ Odds Ratio } \\
\hline High blood pressure & 22.0 & 19.8 & 18.5 & 1.00 & 0.88 & 0.80 \\
\hline Heart disease & 2.7 & 2.9 & 3.3 & 1.00 & 1.08 & 1.21 \\
\hline Stomach or duodenal ulcer & 10.7 & 8.6 & 11.9 & 1.00 & 0.78 & 1.13 \\
\hline Venereal disease & 4.5 & 6.7 & 4.7 & 1.00 & 1.51 & 1.03 \\
\hline Benign fatty tumors & 11.6 & 11.3 & 15.8 & 1.00 & 0.97 & $1.43^{*, \mathrm{~b}}$ \\
\hline Arthritis or rheumatism & 11.9 & 10.7 & 12.5 & 1.00 & 0.88 & 1.06 \\
\hline Hepatitis & 2.0 & 2.0 & 2.0 & 1.00 & 0.99 & 1.04 \\
\hline Chronic bronchitis & 2.5 & 2.5 & 4.5 & 1.00 & 1.03 & 1.86 \\
\hline Genito-urinary problems & 3.7 & 2.7 & 4.1 & 1.00 & 0.73 & 1.11 \\
\hline Nervous system disease & 1.6 & 1.8 & 3.3 & 1.00 & 1.10 & 2.08 \\
\hline Major injury & 10.8 & 11.2 & 10.8 & 1.00 & 1.04 & 1.00 \\
\hline \multicolumn{7}{|l|}{ Questionnaire derived } \\
\hline Adult acne & 11.1 & 9.5 & 15.4 & 1.00 & 0.83 & $1.45^{*, \mathrm{~b}}$ \\
\hline Skin rash with blisters & 17.4 & 19.6 & 22.7 & 1.00 & 1.16 & $1.40^{*, \mathrm{~b}}$ \\
\hline Change in skin color & 7.7 & 8.2 & 9.6 & 1.00 & 1.07 & 1.26 \\
\hline Increased sensitivity to light & 16.6 & 17.9 & 26.1 & 1.00 & 1.10 & $1.77^{* * *, \mathrm{~b}}$ \\
\hline
\end{tabular}

${ }^{a} N$ 's indicate number of men eligible to answer specific questions. Actual number of respondents varied slightly due to missing information.

${ }^{b} \boldsymbol{P}$ value, Mantel-extension test for trend.

${ }^{*} P<0.05 ;{ }^{* * *} P<0.001$.

\section{Health "Symptom Complexes"}

The five "symptom complex" scales, their components, and their reliabilities are given in Table 5; all five proved to be highly reliable, $(\alpha \geqslant 0.64)$, whether evaluated in subjects who had served in Southeast Asia, those who had not, or all subjects combined.

The scales are all mutually correlated $(P<0.001)$. Table 6 gives the correlation coefficients of the five scales with each other, and with level of combat, Agent Orange exposure index OE3, and year of birth. The strongest correlation coefficient was 0.60 (Faint and Fatigue), while the weakest was 0.31 (Faint and Skin). Each symptom scale was positively correlated $(P<0.001)$ with level of combat and OE3; the combat correlations were stronger. None of the scales was correlated with age; therefore, age is not used as a covariate in the symptom scale analysis. (It should be remembered that the study population has a narrow age distribution.)

Analysis of the five "symptom complex" scales was directed to three basic questions. First, do the scale distributions differ significantly between in-country (Southeast Asia) subjects and controls, i.e., those who did not serve in Southeast 
TABLE 4

Percentage Frequency and Odds Ratio in Favor of Having Been Medically Diagnosed with Specific Health Conditions among Veterans Who Served in Southeast Asia, but Who Held No Herbicide-Related Jobs, According to level of Combat Experienced

\begin{tabular}{|c|c|c|c|c|c|c|}
\hline \multirow[b]{2}{*}{ Disease or condition } & \multicolumn{6}{|c|}{ Level of combat } \\
\hline & $\begin{array}{c}\text { Low } \\
N=1209\end{array}$ & $\begin{array}{c}\text { Medium } \\
1084\end{array}$ & $\begin{array}{c}\operatorname{High}^{a} \\
552\end{array}$ & Low & Medium & High \\
\hline Medically diagnosed & \multicolumn{3}{|c|}{ Percentage with history } & \multicolumn{3}{|c|}{ Odds ratio } \\
\hline High blood pressure & 17.7 & 21.2 & 24.4 & 1.00 & 1.25 & $1.50^{* * . \mathrm{b}}$ \\
\hline Heart disease & 2.6 & 3.5 & 4.0 & 1.00 & 1.37 & 1.56 \\
\hline Stomach or duodenal ulcer & 7.3 & 10.9 & 15.2 & 1.00 & 1.55 & $2.26^{* * * *}$ \\
\hline Venereal disease & 5.2 & 6.1 & 3.7 & 1.00 & 1.17 & 0.70 \\
\hline Benign fatty tumors & 9.7 & 12.9 & 17.0 & 1.00 & 1.38 & $1.91^{* * * *}$ \\
\hline Arthritis or rheumatism & 8.6 & 12.2 & 17.6 & 1.00 & 1.46 & $2.26^{* * *}$ \\
\hline Hepatitis & 0.8 & 2.3 & 3.3 & 1.00 & 2.75 & $4.06 * * *$ \\
\hline Chronic bronchitis & 2.5 & 2.7 & 4.2 & 1.00 & 1.08 & 1.70 \\
\hline Genito-urinary problems & 2.0 & 3.9 & 4.6 & 1.00 & 1.93 & $2.32^{* *}$ \\
\hline Nervous system disease & 1.1 & 1.5 & 4.6 & 1.00 & 1.37 & $4.32^{* * *}$ \\
\hline Major injury & 9.8 & 11.9 & 13.3 & 1.00 & 1.25 & $1.41^{*}$ \\
\hline
\end{tabular}

${ }^{a} N$ 's indicate number of men eligible to answer specific questions. Actual number of respondents varied slightly due to missing information.

${ }^{b} P$ value, Mantel-extension test for trend.

${ }^{*} P<0.05 ;{ }^{* *} P<0.01 ;{ }^{* * *} P<0.001$.

Asia? Second, do the scales differ among Southeast Asia veterans who held herbicide-related jobs, compared to in-country veterans who did not? And third, among Southeast Asia veterans without herbicide jobs, how do the scales depend upon combat and incidental exposure to herbicides?

Southeast Asia vs elsewhere. The mean value of each of the five symptom scales was significantly higher (by $t$ test, $P<0.001$ ) in men who served in Southeast Asia than in men who served elsewhere (controls), as shown in Table 7. For instance the mean Fatigue for 2197 in-country subjects was 14.60 ( $\mathrm{SE}=0.10$ ), compared to 13.03 ( $\mathrm{SE}=0.06$ ) for 3021 controls.

Herbicide handlers vs nonhandlers. There were 83 men with these data who served in Southeast Asia and whose jobs specifically involved handling herbicides. The mean value of each of the five symptom scales was significantly higher in this group compared to men who also served in Southeast Asia, but whose jobs were not herbicide related, also shown in Table 7. For instance, the mean value of Aches in the herbicide handlers was 5.57 ( $\mathrm{SE}=0.26)$, compared to 4.68 ( $\mathrm{SE}=$ 0.04) among the remainder of Southeast Asia veterans.

Combat and herbicide effects. While the data in Table 6 show significant correlations between each of the five symptom scales and both combat and herbicide exposure, the table also shows that combat is correlated with exposure to Agent Orange (OE3) $(r=0.24)$. Therefore, a multiple regression approach has been used in which each symptom scale is predicted in turn by the continuous variables combat and OE3. Table 8 gives the standardized regression coefficients $(\beta)$ for 
TABLE 5

Symptom Scales, Components, and Reliabilities (Cronbach $\alpha$ ) in Southeast Asia VETERANS AND CONTROLS ${ }^{a}$

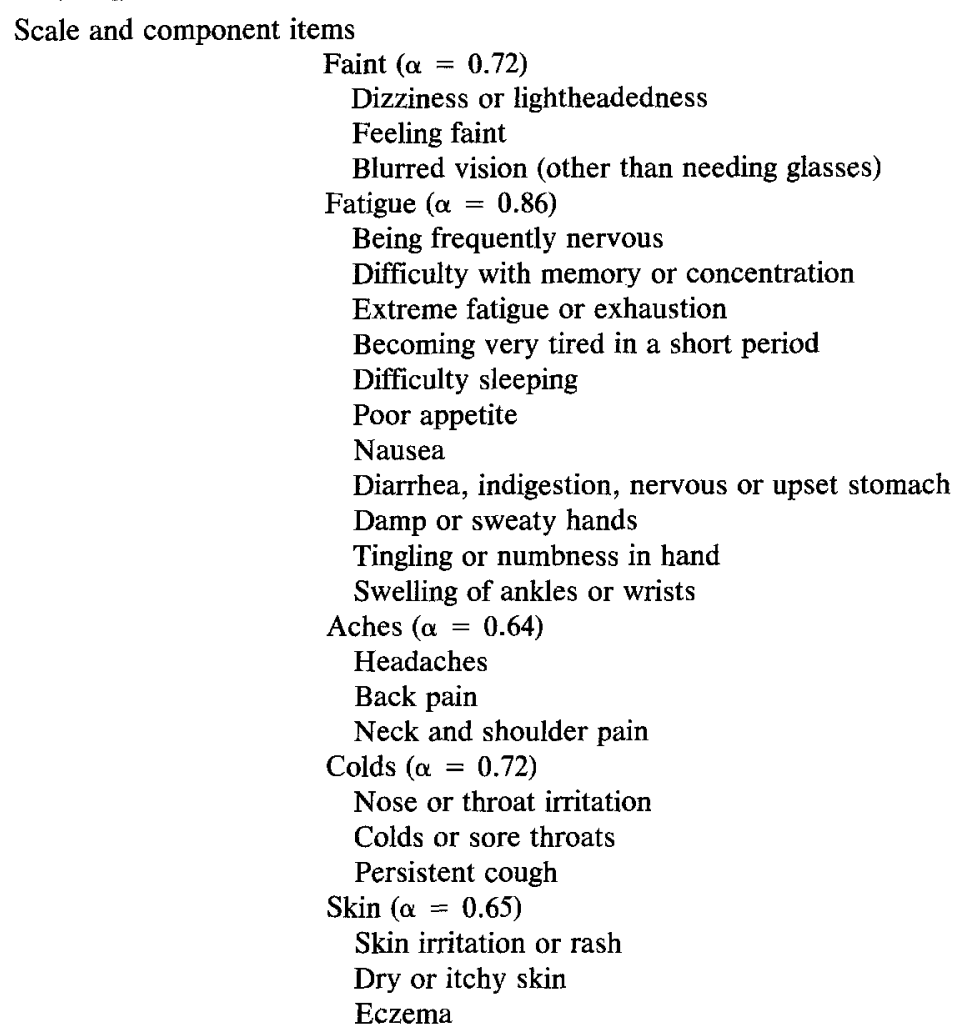

${ }^{a}$ Scales were scored as the sum of component ratings: 1 (not a problem), 2 (minor problem), 3 (a problem), or 4 (really a major problem). Ratings of 2,3 , or 4 were restricted to items which did not preexist military service.

both variables in each of the five regression models. Both combat and Agent Orange exposure were statistically significant and independent predictors of each symptom scale. The $P$ values for combat were all below 0.001 , while those for OE3 were all less than 0.05 (Fatigue and Skin, $P<0.001$; Faint, $P<0.01$; Aches and Colds $P<0.05$ ).

If the relative magnitudes of the $\beta$ 's reflect the relative "contribution" or "importance" of each of the two independent variables as a predictor of a given scale, then combat is always the more "important" variable, since its $\beta$ is generally twice that of OE3. The exception is the scale Faint, where the two $\beta$ 's are nearly the same.

\section{Reproductive Factors}

A number of related factors concerning reproductive history were investigated, ranging from reproductive difficulty to specific birth defects. Because of the ne- 
TABLE 6

Correlation Coefficients of Five Health "Symptom Complex" Scales with Each

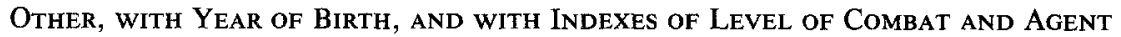
ORANGE EXPOSURE

\begin{tabular}{|c|c|c|c|c|c|c|c|c|}
\hline & Faint & Fatigue & Aches & Colds & Skin & $\begin{array}{l}\text { Year } \\
\text { of } \\
\text { birth }\end{array}$ & Combat & $\begin{array}{c}\text { Agent } \\
\text { Orange } \\
\text { exposure }\end{array}$ \\
\hline Faint & 1.00 & 0.60 & 0.41 & 0.35 & 0.31 & -0.04 & 0.17 & 0.11 \\
\hline Fatigue & & 1.00 & 0.56 & 0.51 & 0.48 & 0.02 & 0.33 & 0.17 \\
\hline Aches & & & 1.00 & 0.37 & 0.33 & -0.01 & 0.21 & 0.10 \\
\hline Colds & & & & 1.00 & 0.37 & -0.01 & 0.19 & 0.10 \\
\hline Skin & & & & & 1.00 & 0.03 & 0.28 & 0.12 \\
\hline Year of birth & & & & & & 1.00 & 0.01 & -0.02 \\
\hline Combat & & & & & & & 1.00 & 0.24 \\
\hline Agent Orange exposure & & & & & & & & 1.00 \\
\hline
\end{tabular}

cessity for obtaining medical verification of birth defects, presentation of these data will be deferred to a future report.

The findings presented in this section are confined to ever-married men born in 1940 or later, in order to eliminate reproductive experiences which occurred be-

TABLE 7

Means $(X)$ and Standard Errors (SE) for Five "Symptom Complex”' Scales ${ }^{a}$

\begin{tabular}{|c|c|c|c|c|c|}
\hline \multirow{4}{*}{$\begin{array}{l}\text { "Symptom Complex" } \\
\text { scale }\end{array}$} & & \multicolumn{4}{|c|}{ Served in Southeast Asia } \\
\hline & & \multirow{3}{*}{$\frac{\text { No }}{\text { Controls }}$} & \multicolumn{3}{|c|}{ Yes } \\
\hline & & & \multirow{2}{*}{$\underset{\text { subjects }^{b}}{\text { All }}$} & \multicolumn{2}{|c|}{ Handled herbicides ${ }^{c}$} \\
\hline & & & & No & Yes \\
\hline \multirow[t]{3}{*}{ Faint } & $X$ & 3.35 & $3.55^{* * *}$ & 3.53 & $3.96^{*}$ \\
\hline & SE & 0.02 & 0.02 & 0.02 & 0.17 \\
\hline & $\mathbf{N}$ & 3543 & 2516 & 2433 & 83 \\
\hline \multirow[t]{3}{*}{ Fatigue } & $X$ & 13.03 & $14.60^{* * *}$ & 14.49 & $17.92^{* * *}$ \\
\hline & SE & 0.06 & 0.10 & 0.10 & 0.85 \\
\hline & $\mathrm{N}$ & 3021 & 2197 & 2124 & 73 \\
\hline \multirow[t]{3}{*}{ Aches } & $X$ & 4.29 & $4.71^{* * *}$ & 4.68 & $5.57^{* *}$ \\
\hline & SE & 0.03 & 0.04 & 0.04 & 0.26 \\
\hline & $\mathrm{N}$ & 3162 & 2312 & 2233 & 79 \\
\hline \multirow[t]{3}{*}{ Colds } & $X$ & 3.47 & $3.79 * * *$ & 3.76 & $4.72^{* * *}$ \\
\hline & $\mathrm{SE}$ & 0.02 & 0.03 & 0.03 & 0.26 \\
\hline & $\mathrm{N}$ & 3179 & 2267 & 2196 & 71 \\
\hline \multirow[t]{3}{*}{ Skin } & $X$ & 3.39 & $3.93^{* * *}$ & 3.90 & $4.89 * * *$ \\
\hline & SE & 0.02 & 0.03 & 0.03 & 0.27 \\
\hline & $N$ & 3460 & 2460 & 2381 & 79 \\
\hline
\end{tabular}

${ }^{a}$ (1) All Southeast Asia subjects vs. controls. (2) Herbicide handlers vs. non-handlers who served in Southeast Asia.

${ }^{b} t$ test, all Southeast Asia vs Controls.

${ }^{c} t$ test, herbicide handlers vs all other Southeast Asia.

${ }^{*} P<0.05 ;{ }^{* *} P<0.01 ;{ }^{* *} P<0.001$. 
TABLE 8

Multiple Regressions of Five Symptom Scales on Leyels of Combat and Agent Orange Exposure for Men Who Served in Southeast Asia, and Who Were Not HERBICIDE HANDLERS

\begin{tabular}{lccccc}
\hline & \multicolumn{5}{c}{ Symptom scale predicted } \\
\cline { 2 - 5 } & Faint & Fatigue & Aches & Colds & Skin \\
\hline Predictor & \multicolumn{5}{c}{ Standardized regression coefficient, $\beta$} \\
Combat & $0.091^{* * *}$ & $0.270^{* * *}$ & $0.172^{* * *}$ & $0.161^{* * *}$ & $0.153^{* * *}$ \\
OE3 $^{a}$ & $0.077^{* *}$ & $0.100^{* * *}$ & $0.059^{*}$ & $0.056^{*}$ & $0.087^{* * *}$ \\
\hline
\end{tabular}

${ }^{a}$ Agent Orange exposure index.

${ }^{*} P<0.05 ;{ }^{* *} P<0.01 ;{ }^{* *} P<0.001$.

fore the Vietnam Era. Of men who had never been married, only 11 who had served in Southeast Asia (7.3\%) and 15 who had served elsewhere (6.6\%) said they had fathered children, and only 5 of these 26 said they were living with a common-law wife at the time of the survey. These men were eliminated from the analysis.

Childbearing attempts. The percentage of ever-married men who said they either had or tried to have children was slightly greater among veterans who served in Southeast Asia than among controls (90.3\% vs $88.4 \%$, Table 9), but even this small difference was statistically significant $(P<0.05)$, and the percentage increased with increasing levels of combat: $89.7,90.1$, and $92.2 \%$ for low, me-

TABLE 9

Child-Bearing Efforts in Relation to Location of Service and Level of Combat

\begin{tabular}{|c|c|c|c|c|c|c|c|c|}
\hline & \multicolumn{4}{|c|}{$\begin{array}{l}\text { Have you ever had } \\
\text { children or tried to } \\
\text { have children? }\end{array}$} & \multicolumn{4}{|c|}{$\begin{array}{l}\text { Have you ever experienced } \\
\text { difficulty in having } \\
\text { children? } ?^{a, b}\end{array}$} \\
\hline & \multicolumn{2}{|c|}{ Yes } & \multicolumn{2}{|c|}{ No } & \multicolumn{2}{|c|}{ Yes } & \multicolumn{2}{|c|}{ No } \\
\hline & Number & $\%$ & Number & $\%$ & Number & $\%$ & Number & $\%$ \\
\hline $\begin{array}{l}\text { Not in Southeast Asiac } \\
\text { Southeast Asia }\end{array}$ & 2537 & 88.4 & 334 & 11.6 & 363 & 14.9 & 2072 & 85.1 \\
\hline $\begin{array}{l}\text { All } \\
\text { Combat level }\end{array}$ & 2011 & $90.3^{d}$ & 215 & 9.7 & 349 & $18.0^{e}$ & 588 & 82.0 \\
\hline Low & 824 & 89.7 & 95 & 10.3 & 122 & 15.4 & 669 & 84.6 \\
\hline Medium & 785 & 90.1 & 86 & 9.9 & 152 & 20.0 & 607 & 80.0 \\
\hline High & 402 & $92.2^{f}$ & 34 & 7.8 & 75 & 19.4 & 312 & 80.6 \\
\hline $\begin{array}{l}{ }^{a} \text { Ever-married men b } \\
{ }^{b} \text { Men who had or tri } \\
{ }^{c} \text { Low combat only. } \\
{ }^{d} \text { SEA vs non-SEA, } \\
{ }^{e} \text { SEA vs non-SEA, } \\
{ }^{f} \text { Mantel-extension tre }\end{array}$ & $\begin{array}{l}1940 \mathrm{o} \\
\text { to have } \\
0.05 \\
0.01 \\
P<0\end{array}$ & $\begin{array}{l}\text { ater. } \\
\text { ildren. }\end{array}$ & & & & & & \\
\hline
\end{tabular}


dium, and high combat, respectively (significant trend, $P<0.01$ ). There was no relationship between childbearing attempts and herbicide exposure

Difficulty having children. Considering only ever-married men born 1940 or later, who said they had tried to have children, Table 9 shows that $18.0 \%$ of those who served in Southeast Asia claimed to have had difficulty, compared to $14.9 \%$ of controls ( $\mathrm{OR}=1.25, P<0.01)$. In the former group, medium- and high-combat veterans had the highest rates $(20.0$ and $19.4 \%$, respectively), while the rate among low-combat veterans, $15.4 \%$, was not significantly different from controls. Despite the elevated percentage among medium- and high-combat subjects, the lack of a dose-response at these two higher levels was in contrast to the uniform gradient observed with nearly all other combat-related outcomes, and suggested a confounding effect. Adjustment for year of birth (five levels: 1940-1943, 1944 $1945,1946-1947,1948-1949,1950+$ ) reduced the effect to nonsignificance in the high-combat group.

An initially significant relationship with Agent Orange exposure became insignificant after adjustment for level of combat.

Delays in fathering. We investigated the hypothesis that various service-related factors, such as combat, might result in delayed childbearing for either physical or social reasons. A variable, Delay, was defined as the time elapsed between the end of military service and the first reported pregnancy of a spouse; subjects were included only if they were born 1940 or later (to eliminate careerists whose childbearing was already past), who had tried to have children, and for whom the first pregnancy occurred not earlier than discharge from service (to eliminate those births which occurred prior to exposures). There were 3078 such subjects. The mean delay (between discharge and first pregnancy fathered) was 4.44 years both in veterans who had served in Southeast Asia and those who had not. Figure 1 shows that the relationship between Delay and education is an approximately linear one. That is, the more highly educated subjects tended to have their first child later in life.

In-depth analysis showed no differences in Delay with respect to any of the following variables: year of birth, income, service in Southeast Asia, level of combat, or herbicide exposure.

Number of pregnancies fathered. Among men meeting the above restrictions, the average number of reported pregnancies fathered was $2.25(\mathrm{SD}=0.94)$. There were no significant or material differences in mean number of pregnancies fathered between in-country subjects and in-service controls, or between groups with different combat or herbicide exposure levels. The distribution of number of pregnancies did not differ according to location of military service, and did not vary significantly with level of combat or Agent Orange exposure.

Miscarriages. The frequency of miscarriage in relation to service history was studied by considering each reported pregnancy as a separate event; the pregnancy outcome is therefore the unit of analysis, rather than the individual veteran. A total of 6622 birth outcomes were reported by the 2950 men analyzed. Of these, $6080(91.8 \%)$ were live births, $437(6.6 \%)$ were miscarriages, $59(0.9 \%)$ were reported as stillbirths, and $46(0.7 \%)$ were abortions. Because of small numbers of abortions and stillbirths, only live birth and miscarriage outcomes were analyzed. 


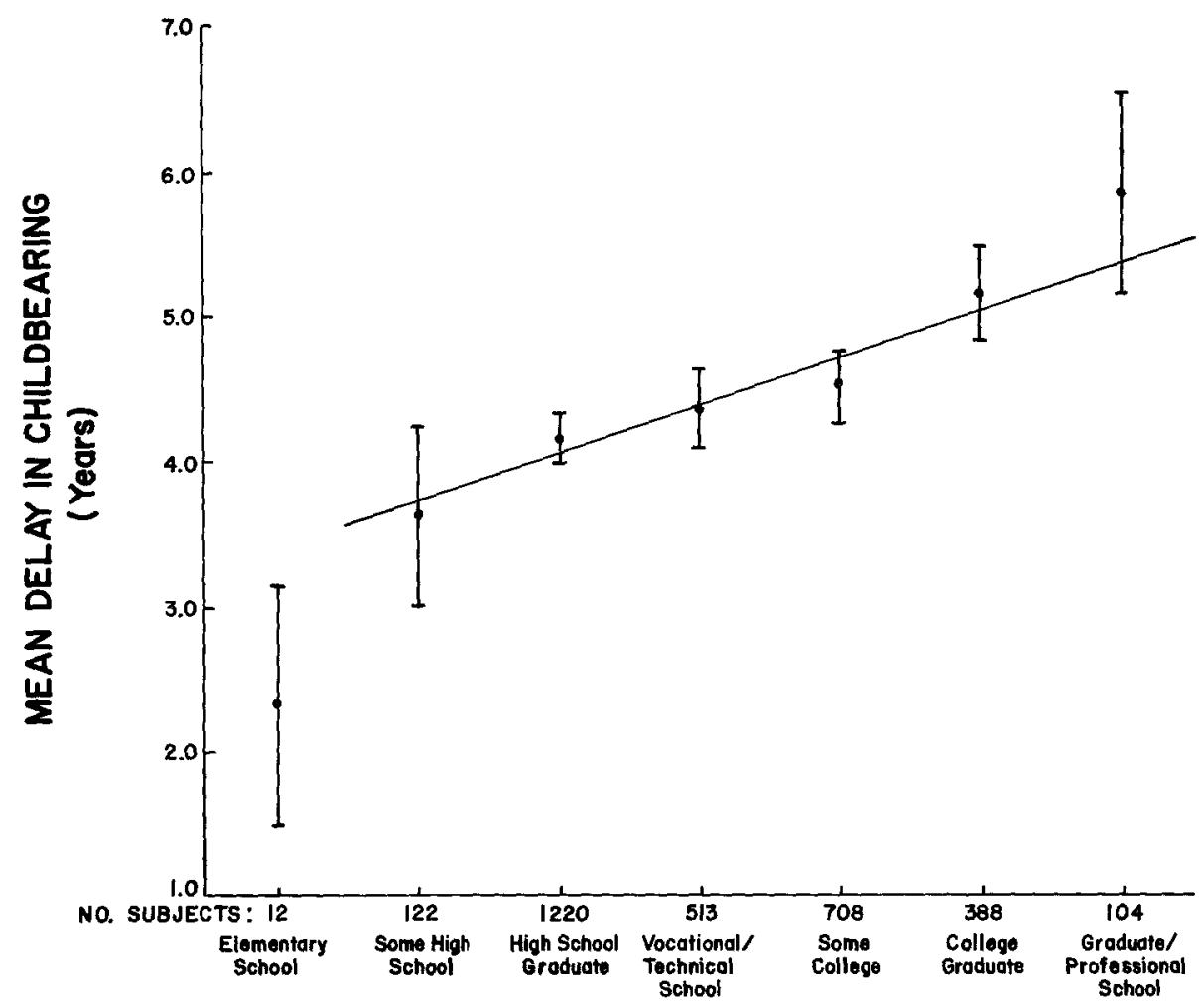

FIG. 1. Mean years between separation from military service and birth of first child. Vertical bars denote $95 \%$ confidence limits.

The crude miscarriage rates are shown in Table 10, according to service in Southeast Asia or elsewhere, level of combat, and exposure to Agent Orange. The rate among Southeast Asia veterans, $7.6 \%$, was significantly greater than that $(5.8 \%)$ among those who did not serve there $(\mathrm{OR}=1.35, P<0.01)$. The rate increased with combat (from $7.1 \%$ in the low-combat group to $10.2 \%$ in the high-combat group), and with Agent Orange exposure (from 7.3\% at low exposure to $9.6 \%$ at high exposure). While these overall trends were not statistically significant, the rates in both the high-combat group and the high-exposure group were significantly higher than in the low-combat controls.

Since combat and Agent Orange exposure are correlated with each other (Table 6 and Paper 1: Figs. 5 and 6), different ways of adjusting the effects of one for the other were considered. In addition, because birth outcomes are often related to age of parents and to mother's smoking habit, it was important also to investigate the influence of adjustment for these factors on miscarriage rates. Two types of analyses were done: analysis of variance and covariance, to see how the mean combat and herbicide levels differed between birth outcomes; and logistic regression, to predict birth outcome as a function of a number of independent variables, including the foregoing exposures.

Miscarriages: Analysis of variance. The mean value of combat and of Agent 
TABLE 10

Number of Reported Live Births and Miscarriages according to Location of Service, LeVel of Combat, and Agent Orange Exposure

\begin{tabular}{lcccccc} 
& $\begin{array}{c}\text { Total No. } \\
\text { miscarriages } \\
\text { and live births }\end{array}$ & $\begin{array}{c}\text { Percentage } \\
\text { miscarriages }\end{array}$ & \multicolumn{2}{l}{ Odds ratio in favor of miscarriages } \\
\hline $\begin{array}{l}\text { Not in Southeast Asia }{ }^{a} \\
\text { Served in Southeast Asia }\end{array}$ & 3364 & $5.8 \%$ & $1.00^{b}$ & $1.00^{b}$ & & \\
$\quad$ All & 3046 & 7.6 & $1.35^{* * *}$ & & & \\
$\quad$ Level of combat & & & & 1.25 & $1.00^{b}$ & $1.00^{b, c}$ \\
$\quad$ Low & 1227 & 7.1 & & 1.25 & 1.00 & $0.83^{c}$ \\
$\quad$ Medium & 1253 & 7.1 & & $1.86^{* * *}$ & $1.49^{* *}$ & $1.18^{c}$ \\
$\quad$ High & 558 & 10.2 & & 1.29 & $1.00^{b}$ & $1.00^{b, d}$ \\
Agent Orange exposure & & & & 1.51 & 1.17 & $1.16^{d}$ \\
$\quad$ Low & 984 & 7.3 & & 1.74 & 1.35 & $1.26^{d}$ \\
$\quad$ Medium & 627 & 8.5 & & $1.58^{* * *}$ & 1.23 & $e$ \\
$\quad$ High & 604 & 9.6 & & & \\
Handled herbicides & 102 & 8.8 & & & \\
\hline
\end{tabular}

Note. Restricted to ever-married men born 1940 or later, discharged 1974 or earlier, who had had or tried to have children, with the first pregnancy reported subsequent to discharge.

${ }^{a}$ Low-combat.

${ }^{b}$ Reference category.

${ }^{c}$ Adjusted for Agent Orange.

${ }^{d}$ Adjusted for combat.

${ }^{e}$ Too few cases for stratified analysis.

${ }^{* *} P<0.01 ;{ }^{* * *} P<0.001$.

Orange exposure were analyzed separately by one-way ANOVA in relation to outcome (either live birth or miscarriage), and by two-way ANOVA with either mother's smoking or mother's age as the second independent variable. Each etiologic variable was also added as a covariate when the other was the dependent variable. Mother's smoking was coded zero if she did not smoke during the index pregnancy, 1 if she smoked less than one pack per day at that time, and 2 if she smoked at least one pack per day. Results are shown in Table 11.

Mean levels of Agent Orange exposure were always significantly higher in pregnancies which ended in miscarriage, compared to those that ended in live births, irrespective of mother's age or smoking habit, and irrespective of whether combat was added as a covariate.

On the other hand, combat did not differ significantly between the two birth outcomes except when mother's age was added as a second independent variable, and even then the difference became insignificant after adjustment for Agent Orange exposure.

Miscarriages: Logistic regression. Analysis was restricted to pregnancies which ended in either a live birth or a miscarriage, fathered by veterans who served in Southeast Asia, who were not herbicide handlers, and who had valid scores for the following variables: Agent Orange exposure, combat, father's year of birth, mother's smoking history during pregnancy, and both mother's and father's ages at date of outcome. There were 2213 outcomes which qualified. 
TABLE 11

analysis of Variance and Covariance Mean: Combat or Agent Orange Exposure

\begin{tabular}{|c|c|c|c|c|}
\hline $\begin{array}{l}\text { Dependent } \\
\text { variable }\end{array}$ & $\begin{array}{l}\text { Independent } \\
\text { variable(s) }\end{array}$ & $P$ value & Covariate & $\begin{array}{l}P \text { value for } \\
\text { covariate }\end{array}$ \\
\hline Agent Orange & Outcome $^{a}$ & $<0.05$ & Combat & $<0.001$ \\
\hline Agent Orange & $\begin{array}{l}\text { Outcome } \\
\text { Mother's age }\end{array}$ & $\begin{array}{c}<0.001 \\
\text { n.s. }\end{array}$ & & \\
\hline Agent Orange & $\begin{array}{l}\text { Outcome } \\
\text { Mother's age }\end{array}$ & $\begin{array}{c}<0.001 \\
\text { n.s. }\end{array}$ & Combat & $<0.001$ \\
\hline Agent Orange & $\begin{array}{l}\text { Outcome } \\
\text { Mother's smoking }\end{array}$ & $\begin{array}{l}0.001 \\
\text { n.s. }\end{array}$ & & \\
\hline Agent Orange & $\begin{array}{l}\text { Outcome } \\
\text { Mother's smoking }\end{array}$ & $\begin{array}{c}<0.01 \\
\text { n.s. }\end{array}$ & Combat & $<0.001$ \\
\hline $\begin{array}{l}\text { Combat } \\
\text { Combat }\end{array}$ & $\begin{array}{l}\text { Outcome } \\
\text { Outcome } \\
\text { Mother's age }\end{array}$ & $\begin{array}{c}\text { n.s. } \\
<0.05 \\
0.06\end{array}$ & Agent Orange & $<0.001$ \\
\hline Combat & $\begin{array}{l}\text { Outcome } \\
\text { Mother's age }\end{array}$ & $\begin{array}{l}\text { n.s. } \\
0.05\end{array}$ & Agent Orange & $<0.001$ \\
\hline Combat & $\begin{array}{l}\text { Outcome } \\
\text { Mother's smoking }\end{array}$ & $\begin{array}{l}0.02 \\
\text { n.s. }\end{array}$ & & \\
\hline Combat & $\begin{array}{l}\text { Outcome } \\
\text { Mother's smoking }\end{array}$ & $\begin{array}{l}\text { n.s. } \\
\text { n.s. }\end{array}$ & Agent Orange & $<0.001$ \\
\hline
\end{tabular}

a"Outcome" = live birth or miscarriage. Restricted to men who served in Southeast Asia and who were not herbicide handlers. n.s. = not significant.

Logistic regression was used to predict the outcome ( 0 for live birth, 1 for miscarriage) as a function of combinations of the above six independent variables. It was immediately found that three variables, father's year of birth, mother's age, and father's age, had no predictive effect on the outcome $(P>0.05)$ and these variables were not considered further.

Only coefficients for Agent Orange exposure and mother's smoking habit were statistically significant $(P=0.004$ and 0.010 , respectively). Combat was not a significant predictor $(P>0.1)$. Figure 2 shows the predicted miscarriage rates based upon this model (which is, of course, fitted to our study data). The model predicts, for example, an increase from the baseline rate of $5.0 \%$ (zero exposure, mother did not smoke while pregnant) to $8.54 \%$ for a father with an exposure score of 2.0 if his wife did not smoke, or $11.7 \%$ if she smoked a pack or less per day. However, it should be noted that only $7 \%$ of all birth outcomes occurred to veterans whose exposure index exceeded 1.0 , and only $4 \%$ to those with an index of 2.0 or more.

Sex of live born children. The sex ratio among live born children was investigated to see whether it was influenced by any of the variables under study. A slightly higher (but not significantly so) proportion of boys was born to Southeast Asia veterans (52.3\%) compared to controls (50.0\%). Sex of child was not related to level of combat or herbicide, age of father, age of mother, or smoking habit of mother.

Birthweight. One of the most sensitive and important indicators of infant health is weight at time of birth. We studied the relation between the birthweight for 6081 


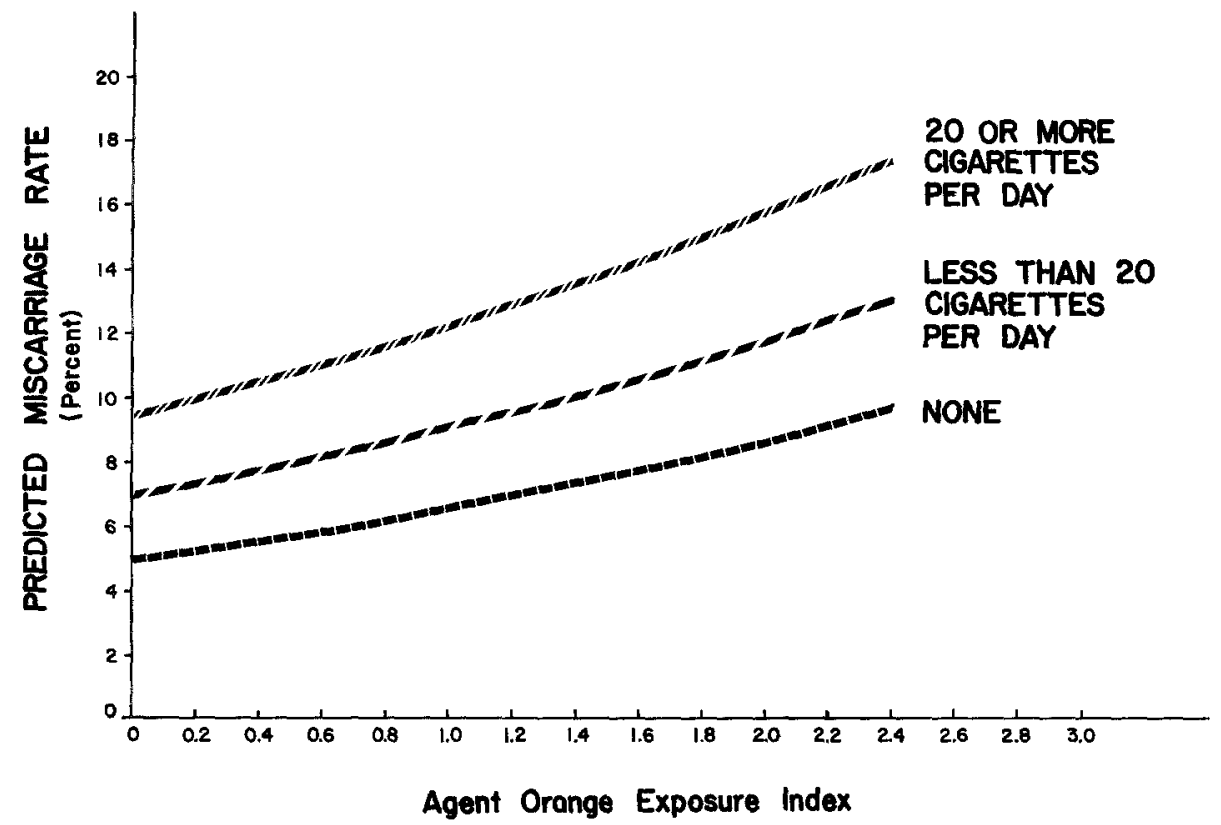

FIG. 2. Rate of miscarriage (per hundred pregnancies) according to father's Agent Orange exposure score and mother's smoking habit, as predicted by logistic regression model.

reported live-born children and the following variables: sex of child, age of father at time of child's birth, age of mother, mother's smoking habit during pregnancy, military service in Southeast Asia, and exposure to combat and to Agent Orange.

The mean birthweight for boys was $7.65 \mathrm{lb}$ and for girls was $7.36 \mathrm{lb}(P<0.001)$. There was no difference between the birthweights of boys born to servicemen stationed in Southeast Asia compared to those born to controls, nor did girls' birthweights differ between these two groups.

Birthweight for babies of each sex was significantly related to both father's and mother's age at time of birth, and to mother's smoking habit. Figure 3 shows the increase in average birthweight with increasing father's age. The figure also shows a similar increase with mother's age, except that the birthweight relation exhibits a downturn after age 35. It is difficult if not impossible to distinguish these two effects from each other in this study population, because of the high correlation between father's and mother's ages.

Figure 4 illustrates the dramatic decrease in average birthweight in both boys and girls which occurs with increasing levels of mother's smoking habit during pregnancy, and underscores the major role smoking plays in fetal development.

There was no relationship between combat in Vietnam and birthweight for either sex, nor was there a relation between herbicide exposure and birthweight, allowing for adjustment for the foregoing variables, singly or in combination.

\section{DISCUSSION}

As could be expected from the literature, we have found significant dose-related 

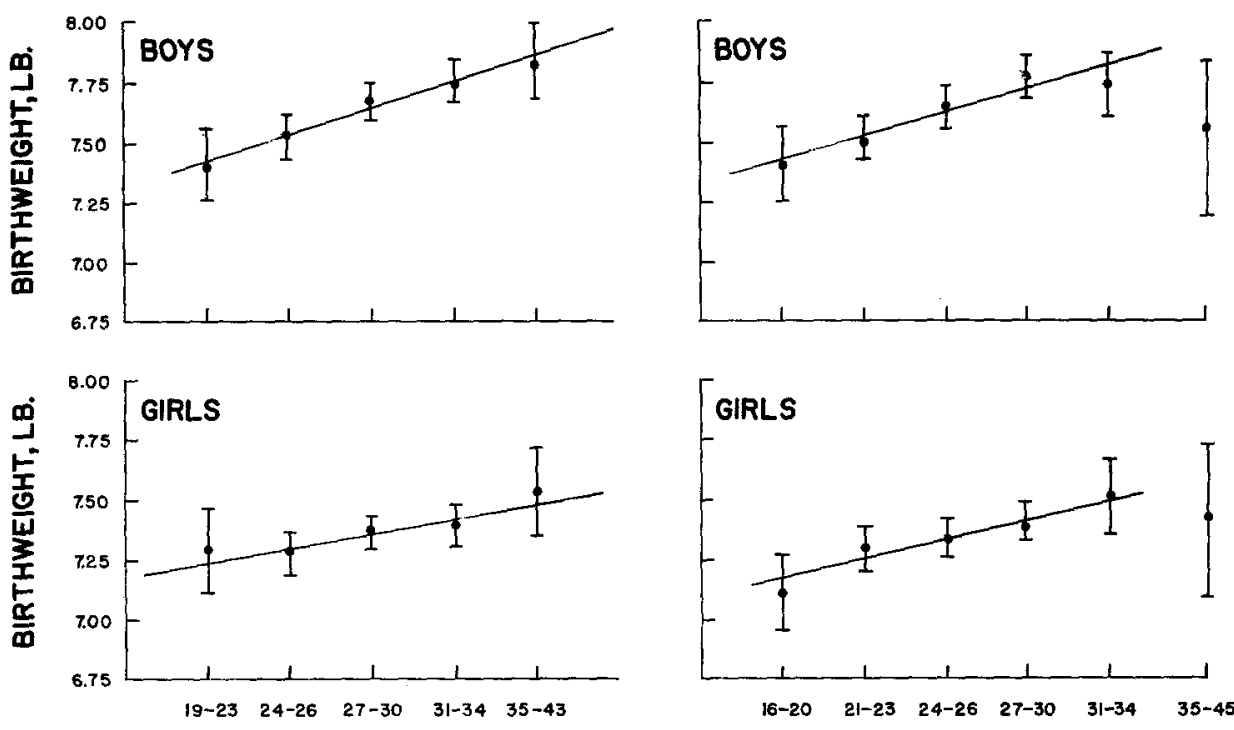

FATHER'S AGE

MOTHER'S AGE

FIG. 3. Mean birthweight of boys and girls by father's age and by mother's age. Vertical bars denote 95\% confidence limits. Regression line is superimposed.

relationships between exposure to herbicides and subsequent development of skin conditions such as rash with blisters and change in skin color. A significant excess of benign fatty tumors was also observed. With respect to combat, it appears that high blood pressure, ulcers, arthritis, and hepatitis are significantly related. Al-
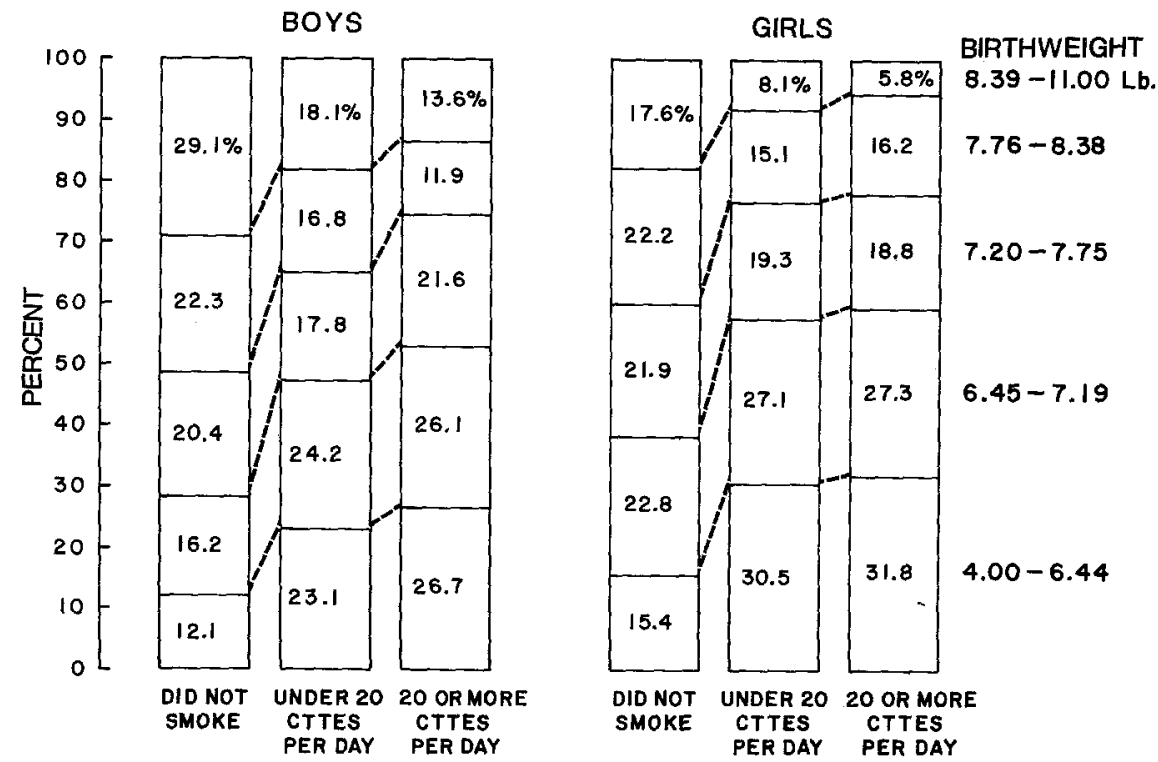

FIG. 4. Distribution of birthweight of boys and girls, according to mother's smoking habit. 
though we did not specifically study sexual practices, the higher rate of venereal disease observed among men serving in a war zone compared to men serving elsewhere is readily plausible.

With regard to reproductive health, our data show a dose-related risk for miscarriage among wives of Agent Orange-exposed veterans. We believe this finding to be especially noteworthy, since we simultaneously observed-and statistically controlled-the independent effects of maternal smoking and age on miscarriage rates. Maternal smoking also exhibited a powerful effect on birthweight (Fig. 4). Observation of such well-established effects tends to confirm the overall validity of the study with respect to reproductive outcomes.

The variable and often ill-defined nature of health conditions which have been associated with exposure to phenoxy herbicides and to stressors, like combat, in many studies cited make the use of "symptom complex" scales seem especially attractive, because these scales condense otherwise diffuse information in a meaningful way. We found that both exposures contributed independently to each of the five symptom complex scales investigated, although the predictive power of combat was usually stronger. These strong relationships serve to underscore the meaningfulness of the factor-analytic approach used.

It is essential to note that while the manifold effects noted in this study span a wide range of outcomes, they are by no means haphazard, but in fact constitute a set of highly specific endpoints, most of which were initially chosen for study because of previous reports in the literature on exposure to stress and to phenoxy herbicides or TCDD (Young et al., 1978; Suskind and Hertzberg, 1984).

The relative frequencies of these outcomes, whenever they differed among subgroups, fell into an order which is consistent with our initial hypothesis, namely, that medical and reproductive conditions would be higher in Vietnam veterans than in controls, that stress-related conditions would increase with exposure to combat, and that herbicide-related conditions would increase in a doserelated way, reaching their greatest frequencies among herbicide handlers.

It is reasonable to believe that herbicide handlers were exposed to high levels of phenoxy herbicides, and that the extensive symptomatology noted in the handlers is directly due to those exposures. There is ample documentation of systemic exposure to 2,4-D and 2,4,5-T among professional applicators. Lavy et al. (1980) measured the dermal and respiratory exposure of back pack, tractor, and helicopter crews, and found that the degree of exposure was related to the worker's job. These workers excreted GC-detectable quantities of 2,4,5-T, even at "subtoxic" levels of exposure. In studies of forest workers exposed to 2,4-D applied by helicopter, Lavy et al. (1982) found that crewmen working most closely with the spray concentrate or handling spray equipment (pilots, mechanics, and batchman-loaders) received the highest doses. Kolmodin-Hedman and colleagues (1983) found significant urinary levels among both farmers and professional spray applicators even when exposed to air concentrations below $0.001 \mathrm{mg} / \mathrm{m}^{3}$.

Exposure of herbicide handlers to phenoxy herbicides would seem to be the most obvious explanation for their high rates of skin rash with blisters and of changes in skin color, and might even be considered as a measure of validation of their self-reported job descriptions. 
The weak but statistically significant dependence of increased "nervous system disease" on both combat and herbicide exposure is consistent with both experimental and clinical studies and deserves further investigation. Abnormalities in nerve conduction velocity have been reported in 2,4,5-T-and 2,4-D-exposed workers (Singer et al., 1982). A Polish study found EEG changes in farm workers assigned to transport 2,4-D derivatives (Kontek et al., 1973). Experimentally, 2,4-D given by gavage to rats increased fore- and hind-limb grip strength, suggesting that it may increase myotonia, a condition characterized by difficulty in relaxation of skeletal musculature following forceful contraction (Squibb et al., 1983).

While skin conditions, especially chloracne, constitute an important observable marker in dioxin-exposed groups, their occurrence is not inevitable, even among the heavily exposed. For instance, Suskind and Hertzberg (1984) observed persistent clinical chloracne in only $55.7 \%$ of 204 "clearly exposed" workers 30 years after the Nitro, West Virginia trichlorophenol accident. Persistent skin problems continue to be a marker for exposure, and are frequently found to be associated with other, more variable clinical signs, including conditions exhibited by herbicide handlers in this study. Workers at a 2,4,5-T manufacturing plant who had chloracne also exhibited an increased prevalence of abnormal GGT and abnormal sensory findings, as well as increased sexual dysfunction and decreased libido (Singer et al., 1982; Moses et al., 1984). An Italian study (Caramaschi et al., 1981) found that children who experienced chloracne following the Seveso accident also had higher rates of gastrointestinal disturbances, and another Italian group observed alteration in SGT and AAT activity in children exposed to the highest concentration of TCDD following the Seveso accident (Mocarelli et al., 1986). A Czechoslovakian study of 55 individuals exposed to TCDD, 95\% of whom developed chloracne, also found numerous metabolic disturbances such as porphyria cutanea tarda, elevated blood lipids, and peripheral neural lesions of lower extremities, as verified by EMG (Pazderova-Vejlupkova et al., 1981).

These findings on physical and reproductive health are consistent with and mutually reinforce the conclusions of the other papers in this series concerning the pervasive effects of combat and herbicide exposure on the lives of veterans of the Vietnam War.

\section{REFERENCES}

Bailey, C., Baron, R. C., Basanac, E., et al. (1986). "West Virginia Vietnam Era Veterans Mortality Study. West Virginia Residents 1968-1983, Preliminary Report." West Virginia Health Department, Charleston.

Bogen, G. (1979). Symptoms in Vietnam veterans exposed to Agent Orange (letter). J. Amer. Med. Assoc. 242, 2391.

Breslin, P., Kang, H. K., Lee, Y., Burt, V., and Shepard, B. M. (1988). Proportionate mortality study of U.S. Army and U.S. Marine Corps veterans of the Vietnam War. J. Occup. Med. 30, 412-419.

Caramaschi, F., Del Corno, G., Favaretti, C., Giambelluca, S. E., Montesarchio, E., and Fara, G. M. (1981). Chloracne following environmental contamination by TCDD in Seveso, Italy. Int. J. Epidemiol. 10, 135-144.

Centers for Disease Control (1987). Postservice mortality among Vietnam veterans. The Centers for Disease Control Vietnam Experience Study. J. Amer. Med. Assoc. 257, 790-795.

Collins, T. F. X., and Williams, C. H. (1971). Teratogenic studies with 2,4,5-T and 2,4-D in the hamster. Bull. Environ. Contam. Toxicol. 6, 559-567. 
Courtney, K. D., and Moore, J. A. (1971). Teratology studies with 2,4,5-trichlorophenoxyacetic acid and 2,3,7,8-tetrachlorodibenzo-p-dioxin. Toxicol. Appl. Pharmacol. 20, 396-403.

DiDomenico, A., Silano, V., Viviano, G., and Zapponi, G. (1980). Accidental release of 2,3,7,8tetrachlorodibenzo-p-dioxin (TCDD) at Seveso, Italy. V. Environmental persistence of TCDD in soil. Ecotoxicol. Environ. Safety 4, 339-345.

Donovan, J. W., MacLennan, R., and Adena, M. (1984). Vietnam service and the risk of congenital anomalies. A case-control study. Med. J. Aust. 140, 394-397.

Erickson, J. D., Mulinare, J., McClain, P. W., Fitch, T. G., James, L. M., McClearn, A. B., and Adams, M. J. (1984a). Vietnam veterans' risks for fathering babies with birth defects. J. Amer. Med. Assoc. 252, 903-912.

Erickson, J. D., Mulinare, J., McClain, P. W., Fitch, T. G., James, L. M., McClearn, A. B., and Adams, M. J. (1984b). "Vietnam Veterans' Risks for Fathering Babies With Birth Defects." Centers for Disease Control, Atlanta.

Eriksson, M., Hardell, L., Berg, N. O., et al. (1981). Soft-tissue sarcomas and exposure to chemical substances: A case-referent study. Brit. J. Ind. Med. 38, 27-33.

Fenton, B. K. (1984). A fatal case of 2,4-D toxicity? Vet. Rec. June 16, 1984, 599.

Fett, M. J., Adena, M. A., Cobbin, D. M., and Dunn, M. (1987a). Mortality among Australian conscripts of the Vietnam conflict era. I. Death from all causes. Amer. J. Epidemiol. 125, 869-877.

Fett, M. J., Nairn, J. R., Cobbin, D. M., and Adena, M. A. (1987b). Mortality among Australian conscripts of the Vietnam conflict era. II. Causes of death. Amer. J. Epidemiol. 125, 878-884.

Figley, C. R. (1978). Psychosocial adjustment among Vietnam veterans. In "Stress Disorder Among Vietnam Veterans" (C. R. Figley, Ed.). Brunner/Mazel, New York.

Frye, J. S., and Stockton, R. A. (1982). Discriminant analysis of posttraumatic stress disorder among a group of Vietnam veterans. Amer. J. Psychiatry 139, 52-56.

Goldstein, N. P., Jones, P. H., and Brown, J. R. (1959). Peripheral neuropathy after exposure to an ester of dichlorophenoxyacetic acid. J. Amer. Med. Assoc. 171, 1306-1309.

Grant, W. F. (1979). The genotoxic effects of 2,4,5-T. Mutat. Res. 65, 83-119.

Hardell, L., Eriksson, M., Lenner, P., and Lundgren, E. (1981). Malignant lymphoma and exposure to chemicals, especially organic solvents, chlorophenols and phenoxy acids: A case-control study. Brit. J. Cancer 43, 169-176.

Hardell, L., and Sandstrom, A. (1979). Case-control study: Soft-tissue sarcomas and exposure to phenoxyacetic acids or chlorophenols. Brit. J. Cancer 39, 711-717.

Herxheimer, K. (1901). Weitere mitteilungen uber chloracne. In "VII Dermatological Kongress, Breslau." p. 152.

Hoar, S. K., Blair, A., Holmes, F. F., Boysen, C. D., Robel, R. J., Hoover, R., and Fraumeni, J. F., Jr. (1986). Agricultural herbicide use and risk of lymphoma and soft-tissue sarcoma. J. Amer. Med. Assoc. 256, 1141-1147.

Hoffman, R. E., Stehr-Green, P. A., Webb, K. B., Evans, R. G., Knutsen, A. P., Schramm, W. F., Staake, J. L., Gibson, B. B., and Steinberg, K. K. (1986). Health effects of long-term exposure to 2,3,7,8-tetrachlorodibenzo-p-dioxin. J. Amer. Med. Assoc. 255, 2031-2038.

Hood, R. D., Patterson, B. L., Thacker, G. T., Sloan, G. L., and Szczech, G. M. (1979). Prenatal effects of 2,4,5-T, 2,4,5-trichlorophenol, and phenoxyacetic acid in mice. J. Environ. Sci. Health C13, 189-204.

Huff, J. E., Moore, J. A., Saracci, R., and Tomatis, L. (1980). Long-term hazards of polychlorinated dibenzodioxins and polychlorinated dibenzofurans. Environ Health Perspect. 36, 221-240.

International Agency for Research on Cancer (1977). Some fumigants, the herbicides 2,4-D and 2,4,5T, chlorinated dibenzodioxins and miscellaneous industrial chemicals. In "IARC Monograph 15: Evaluation of the Carcinogenic Risk of Chemicals to Man." IARC, Lyon.

Kearny, P. C., Woolson, E. A., and Ellington, C. P., Jr. (1972). Persistence and metabolism of chlorodioxins in soils. Environ. Sci. Technol. 6, 1017-1019.

Kociba, R. J., Keys, D. G., Beyer, J. E., Carreon, R. M., Wade, C. E., Dittenber. D. A., Kalnins, R. P., Frauson, L. E., Park, C. N., Barnard, S. D., Hummel, R. A., and Humiston, C. G. (1978). Results of a 2 year chronic toxicity and oncogenicity study of 2,3,7,8-tetrachlorodibenzo- $p$-dioxin in rats. Toxicol. Appl. Pharmacol. 46, 279-303.

Kogan, M. D., and Clapp, R. W. (1985). "Mortality Patterns among Vietnam Veterans in Massachu- 
setts, 1972-83." Massachusetts Office of Commissioner of Veterans Services, Agent Orange Program, Massachusetts Department of Public Health, Division of Health Statistics.

Kolmodin-Hedman, B., Hoglund, S., and Akerblom, M. (1983). Studies on phenoxy acid herbicides. I. Field Study. Occupational exposure to phenoxy acid herbicides (MCPA, dichlorprop, mecoprop, and 2,4-D) in agriculture. Arch. Toxicol. 54, 257-265.

Kontek, M., Marcinkowska. B., and Pietraszek, Z. (1973). Electroencephalographic investigations in farm workers exposed to derivatives of arylalkanocarboxyl acids. Pol. Tyg. Lek. 28, 937-939.

Lathrop, G. D., Wolfe, W. H., Albanese, R. A., and Moynahan, P. M. (1984). "An Epidemiologic Investigation of Health Effects in Air Force Personnel following Exposure to Herbicides. Baseline Morbidity Study Results." USAF School of Aerospace Medicine, Brooks Air Force Base.

Lavy, T. L., Shepard, J. S., and Mattice, J. D. (1980). Exposure measurements of applicators spraying (2,4,5-trichlorophenoxy) acetic acid in the forest. J. Agric. Food Chem. 28, 626-630.

Lavy, T. L., Walstad, J. D., Flynn, R. R., and Mattice, J. D. (1982). (2,4-dichlorophenoxy) acetic acid exposure received by aerial application crews during forest spray operations. J. Agric. Food Chem. 30, 375-381.

Lawrence, C. E., Reilly, A. A., Quickenton, P., Greenwald, P., Page, W. F., and Kuntz, A. J. (1985). Mortality patterns of New York State Vietnam veterans. Amer. J. Public Health 75, 277-279.

Levy, L. (1981). "Preventing Work Stress." Addison-Wesley, Reading, MA.

Lynge, E. (1985). A follow-up study of cancer incidence among workers in manufacture of phenoxy herbicides in Denmark. Brit. J. Cancer 52, 259-270.

Mantel, N., and Haenszel, W. (1959). Statistical aspects of the analysis of data from retrospective studies of disease. $J$. Natl. Cancer Inst. 22, 719-748.

Mantel, N. (1963). Chi-square tests with one degree of freedom; extensions of the Mantel-Haenszel procedure. J. Amer. Stat. Assoc. 58, 690-700.

May, G. (1973). Chloracne from the accidental production of tetrachlorodibenzodioxin. Brit. J. Ind. Med. 30, 276-283.

Mocarelli, P., Marocchi, A., Brambilla, P., Gerthoux, P., Young, D. S., and Mantel, N. (1986). Clinical laboratory manifestations of exposure to dioxin in children. A six-year study of the effects of an environmental disaster near Seveso, Italy. J. Amer. Med. Assoc. 256, 2687-2695.

Moses, M., Lilis, R., Crow, K. D., Thornton, J., Fischbein, A., Anderson, H. A., and Selikoff, I. J. (1984). Health status of workers with past exposure to 2,3,7,8-tetrachlorodibenzo- $p$-dioxin in the manufacture of 2,4,5-trichlorophenoxyacetic acid: comparison of findings with and without chloracne. Amer. J. Indust. Med. 5, 161-182.

Neal, R. A. (1984). Biological effects of 2,3,7,8-tetrachlorodibenzo-p-dioxin in experimental animals. In "Public Health Risks of the Dioxins" (W. W. Lowrance, Ed.), pp 15-29. Kaufmann, Los Altos, CA.

Neubert, D., and Dillmann, I. (1972). Embryotoxic effects in mice treated with 2,4,5-trichlorophenoxyacetic acid and 2,3,7,8-tetrachlorodibenzo-p-dioxin. Arch. Pharmacol. 272, 243-264.

Oliver, R. M. (1975). Toxic effects of 2,3,7,8-tetrachlorodibenzo-1,4-dioxin in laboratory workers. Brit. J. Ind. Med. 32, 49-53.

Patterson, D. G., Hoffman, R. E., Needham, L. L., Roberts, D. W., Bagby, J. R., Pirkle, J. L., Falk, H., Sampson, E. J., and Houk, V. N. (1986). 2,3,7,8-tetrachlorodibenzo-p-dioxin levels in adipose tissue of exposed and control persons in Missouri. An interim report. J. Amer. Med. Assoc. $256,2683-2686$.

Pazderova-Vejlupkova, J., Nemcova, M., Pickova, J., Jirasek, L., and Lukas, E. (1981). The development and prognosis of chronic intoxication by tetrachlorodibenzo-p-dioxin in men. Arch. Environ. Health 36, 5-11.

Pearce, N. E., Smith, A. H., and Fisher, D. O. (1985). Malignant lymphoma and multiple myeloma linked with agricultural occupations in a New Zealand cancer registry based study. Amer. $J$. Epidemiol. 121, 225-237.

Pearce, N. E., Smith, A. H., Howard, J. K., Sheppard, R. A., Giles, H. J., and Teague, C. A. (1986). Non-Hodgkin's lymphoma and exposure to phenoxyherbicides, chlorophenols, fencing work, and meat works employment: A case-control study. Brit. I. Ind. Med. 43, 75-83.

Poland, A., Smith, D., Metter, G., and Possick, P. (1971). A health survey of workers in a 2,4-D and 2,4,5-T plant. Arch. Environ. Health 22, 316-327. 
Roberts, W. R., Penk, W. E., Gearing, M. L., Robinowitz, R., Dolan, M. P., and Patterson, C. T. (1982). Interpersonal problems of Vietnam combat veterans with symptoms of posttraumatic stress disorder. J. Abnor. Psychol. 91, 444-450.

Rowe, V. K., and Hymas, T. A. (1954). Summary of toxicological information on 2,4-D and 2,4,5-T type herbicides and an evaluation of the hazards to livestock associated with their use. Amer. $J$. Vet. Res. 15, 662-629.

Schwetz, B. A., Sparschu, G. L., and Gehring, P. J. (1971). The effect of 2,4-dicholorphenoxyacetic acid (2,4-D) and ester of 2,4-D on rat embryonal, foetal and neonatal growth and development. Food Cosmet. Toxicol. 9, 801-817.

Schwetz, B. A., Norris, J. M., Sparschu, G. L., Rowe, V. K., Gehring, P. J., Emerson, J. L., and Gerbig, C. G. (1973). Toxicology of chlorinated dibenzo-p-dioxins. Environ. Health Perspect. 5, 87-99.

Singer, R., Moses, M., Valciukas, J., Lilis, R., and Selikoff, I. J. (1982). Nerve conduction velocity studies of workers employed in the manufacture of phenoxy herbicides. Environ. Res. 29, 297311.

Squibb, R. E., Tilson, H. A., and Mitchell, C. L. (1983). Neurobehavioral assessment of 2,4dichlorophenoxyacetic acid (2,4-D) in rats. Neurobehav. Toxicol. Teratol. 5, 331-335.

Stellman, S. D., and Stellman, J. M. (1980). "Health Problems among 535 Vietnam Veterans Potentially Exposed to Toxic Herbicides." Paper presented at the Society for Epidemiologic Research. Minneapolis, June, 1980.

Stellman, S. D., and Stellman, J. M. (1986). Estimation of exposure to Agent Orange and other defoliants among American troops in Vietnam: A methodological approach. Amer. J. Ind. Med. 9, 305-321.

Stellman, S. D., Stellman, J. M., and Sommer, J. F., Jr. (1988a). Combat and herbicide exposure in Vietnam among a sample of American Legionnaires. Environ. Res. 47, 112-128.

Stellman, J. M., Stellman, S. D., and Sommer, J. F., Jr. (1988b). Social and behavioral consequences of the Vietnam experience among American Legionnaires. Environ. Res. 47, 129-149.

Suskind, R. R., and Hertzberg, V. S. (1984). Human health effects of 2,4,5-T and its toxic contaminants. J. Amer. Med. Assoc. 251, 2372-2380.

Van Miller, J. P., Lalich, J. J., and Allen, J. R. (1977). Increased incidence of neoplasms in rats exposed to low levels of 2,3,7,8-tetrachlorodibenzo-p-dioxin. Chemosphere 9, 537-544.

Vineis, P., Terracini, B., Ciccone, G., Cignetti, A., Colombo, E., Donna, A., Maffi, L., Pisa, R., Ricci, P., Zanini, E., and Comba, P. (1986). Phenoxy herbicides and soft-tissue sarcomas in female rice weeders. A population based case-referent study. Scand. J. Work Environ. Health 13, 9-17.

Wiklund, K., and Holm, L.-E. (1986). Soft-tissue sarcoma risk in Swedish agricultural and forestry workers. J. Natl. Cancer Inst. 76, 229-234.

Woods, J. S., Polissar, L., Severson, R. K., Heuser, L. S., and Kulander, B. G. (1987). Soft tissue sarcoma and non-Hodgkin's lymphoma in relation to phenoxyherbicide and chlorinated phenol exposure in western Washington. J. Natl. Cancer Inst. 78, 899-910.

Young, A. L., Thalken, C. E., Arnold, E. L., Cupello, J. M., and Cockerham, L. G. (1976). "Fate of 2,3,7,8-tetrachlorodibenzo-p-Dioxin (TCDD) in the Environment: Summary and Decontamination Recommendation (USAFA-TR-76-18)." Department of Chemistry and Biological Sciences, U.S. Air Force Academy, CO.

Young, A. L., Calcagani, J. A., Thalken, C. E., and Trembly, J. W. (1978). "The Toxicology, Environmental Fate and Human Risk of Herbicide Orange and Its Associated Dioxin (USAF Occupational and Environmental Health Laboratory (OEHL), Technical Report No. TR-78-92, Final Report)." Brooks Air Force Base, TX: Medical Division. 